\title{
Detection of lead, chromium and cobalt in meats of cattle and buffalo from retails of Mosul city
}

\author{
H.S. Al-Naemi ${ }^{1}$, R.A. Al-Sanjary ${ }^{2}$, R.A. Faraj ${ }^{3}$ and A. Saadi ${ }^{4}$ \\ ${ }^{1,2,3}$ Department of Veterinary Public Health, College of Veterinary Medicine, ${ }^{4}$ Department of General Science, College of \\ Basic Education, University of Mosul, Mosul, Iraq \\ Email: ${ }^{1}$ hibaalnaemi@gmail.com, ${ }^{2}$ ralsanjary61@ uomosul.edu.iq, ${ }^{3}$ ahmedsadihusien@gmail.com
}

(Received September 4, 2019; Accepted October 13, 2019; Available online August 11, 2020)

\begin{abstract}
Lead $(\mathrm{Pb})$, chromium $(\mathrm{Cr})$ and cobalt $(\mathrm{Co})$ were investigated in 160 local and imported meat samples of cattle and buffalo collected from markets of Mosul city by using Atomic Absorption Spectrophotometer (AAS). Results reported mean concentrations of $\mathrm{Pb}$ and $\mathrm{Cr}$ in local cattle meat 0.136 and $0.0651 \mathrm{mg} / \mathrm{kg}$, respectively significantly higher than that reported for Co $0.008 \mathrm{mg} / \mathrm{kg}$. In imported cattle meat, results revealed that Pb presented a mean concentration $0.182 \mathrm{mg} / \mathrm{kg}$ significantly higher than that presented by $\mathrm{Cr}$ and $\mathrm{Co} 0.0486$ and $0.00971 \mathrm{mg} / \mathrm{kg}$, respectively. No significant differences in the mean concentrations of $\mathrm{Pb}, \mathrm{Cr}$ and $\mathrm{Co}$ in local buffalo meat $0.119,0.0896$ and $0.017 \mathrm{mg} / \mathrm{kg}$, respectively, and imported buffalo meat $0.106,0.102$ and $0.041 \mathrm{mg} / \mathrm{kg}$, respectively, were reported. The results revealed that $20 \%$ from each local cattle and buffalo meat samples, $12.5 \%$ from imported cattle meat and $22.5 \%$ from imported buffalo meat were exceeded the maximum permissible limit for lead in meat. Concerning Cr, $2.5 \%$ from imported cattle meat and 5\% from each of local and imported buffalo meat surpassed the maximum acceptable limit. Ultimately, results showed that all samples of local and imported cattle and buffalo meat were within the maximum allowable limits for Co. The hazards of metals on public health was discussed.
\end{abstract}

Keywords: Lead, Chromium, Cobalt, Cattle meat, Buffalo meat

DOI: $10.33899 /$ ijvs.2019.126069.1224, (C2020, College of Veterinary Medicine, University of Mosul.

This is an open access article under the CC BY 4.0 license (http://creativecommons.org/licenses/by/4.0/).

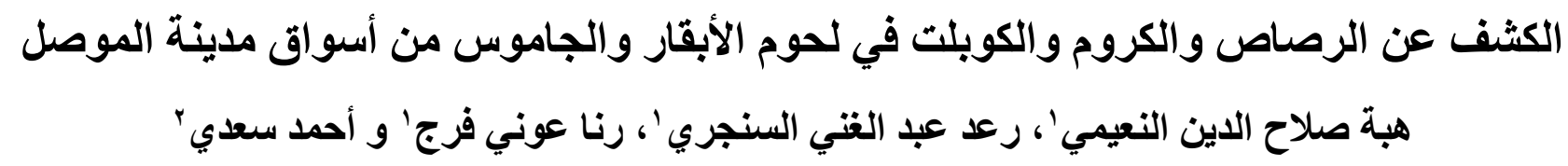

' فرع الصحة العامة البيطرية، كلية الطب البيطري، ؟ فرع العلوم العامة، كلية التربية الأساس، جامعة الموصل، الموصل، العراق

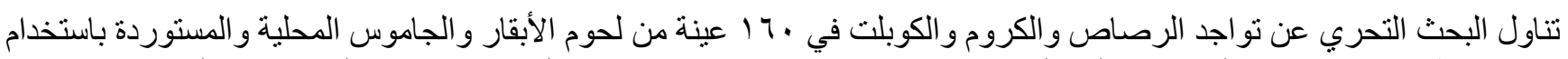

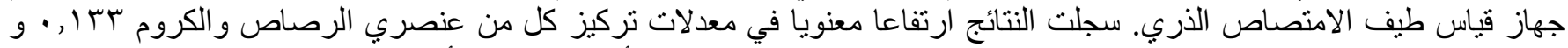

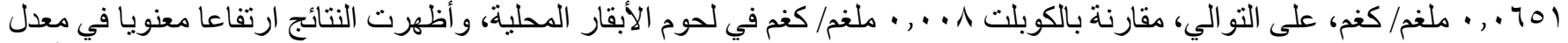

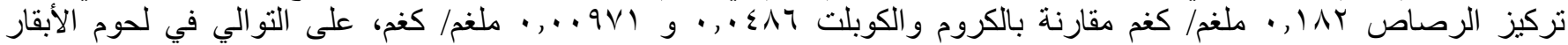

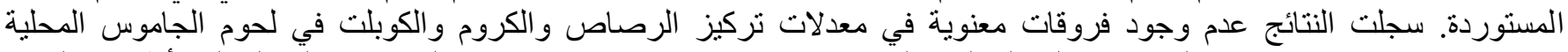

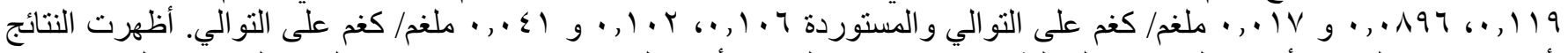

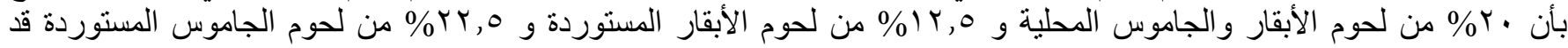

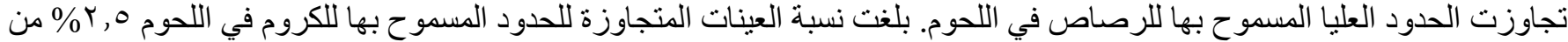
لحوم الأبقار المستوردة و 0\% في كل من لحوم الجاموس المحلية والمستوردة. أخيرا أظهرت النتائج أن جميع عينات لحوم الأبقار

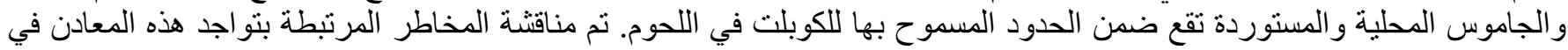
اللحوم على الصحة العامة لمستهلكي هذه اللحوم. 


\section{Introduction}

Meat is an excellent source of high-quality protein, as it provides all essential amino acids necessary for growth and maintenance of our bodies. It is also a valuable source of many vitamins, minerals and trace elements, specially vitamins $\mathrm{B} 3, \mathrm{~B} 6$ and $\mathrm{B} 12$, in addition to iron, zinc and selenium $(1,2)$.

Despite of that meat comprises an important part of human diet, but may constitutes a real threat to human health at the same time when polluted with many hazardous chemicals as heavy metals even in very little quantities (3). Heavy metals are permanently liberated to ecosystems, both terrestrial and aquatic, as a consequence of various human activities.

Cattle and buffalo can be subjected to these metals primarily through drinking water and feed (4). Heavy metals contamination of meat constitutes a significant hazard on human health due to their toxicity and bioaccumulation in human diets $(5,6)$.

Lead has no any recognized biological role in the body. It can adversely affect multiple systems of human body, mainly as a result to interference with wide range of enzymes and finally causing serious disorders on central nervous, hepatic, hematopoietic, reproductive, cardiovascular, endocrinal, gastrointestinal and renal systems (7). Both chromium and cobalt are essential trace metals for humans. Excessive intake of these metals exceeding the acceptable limits can cause many severe adverse effects on human health (8).

Contamination of meat and other edible tissues with heavy metals is a matter of great concern for food safety and human health (9). For this reason, investigation metals level in meat and other edible organs obtained from different animal species were conducted in Iraq (10-12).

In addition to the studies conducted worldwide which highlighted the risks originated from presence of these metals in meat and other products of animal origin which occupy a special importance in human food (13-15). Furthermore, the instances of meat products contamination with heavy metals during processing were reported (16).

Due to the urgent need for a local database and risk assessment studies related to the potential threats originating from contamination of human food of animal origin with heavy metals, we offered this study to investigate some of these metals $\mathrm{Pb}, \mathrm{Cr}$ and $\mathrm{Co}$ in local and imported cattle and buffalo meat, that comprise a serious human health hazard, when they above the maximum permissible limits in meat.

\section{Materials and methods}

A total of 160 local and imported cattle and buffalo meat samples (40 samples for each) were randomly obtained from local markets and butcher shops in Mosul city, northern Iraq from February to May 2013. The samples were placed in polyethylene bags and immediately transported to the laboratory under refrigerated conditions. The samples were stored at $-18^{\circ} \mathrm{C}$ until required after removing of gross fat, main blood vessels and connective tissue (17).

Meat samples were triturated and homogenized inconformity with the method described by (18). Each homogenized sample $5 \mathrm{~g}$ were wet digested with $35 \mathrm{ml}$ of a mixture of high purity concentrated $\mathrm{HNO}_{3}: \mathrm{HClO}_{4}(6: 1 \mathrm{v} / \mathrm{v})$ according to (19). After digestion, slow evaporation for the colorless liquor obtained to near dryness. The residue was cooled and dissolved in $5 \mathrm{~mL}$ of nitric acid 20\%, then diluted with the deionized water to $25 \mathrm{ml}$. Lead, chromium and cobalt were measured using Atomic Absorption Spectrophotometer (GBC SensAA).

Laboratory glassware was firstly cleaned with distilled water, drenched for 48 hours in nitric acid 10\%, then swilled with deionized water for several times and finally air dried. All the reagents used in this study were of analytical grade. The commercial standards for atomic absorption analysis were used which contained the minerals analyzed in a high pure state. Calibration of the instrument with the standards of studied metals were performed before introducing of the sample digest. A recovery test was achieved by inoculating selected analyzed samples with definite concentrations of studied metals, and the samples were reanalyzed. Each analysis was performed in triplicate.

Statistical analysis was performed depending on Two Way Analysis of Variance procedure of the statistical program, Sigma Stat for windows Version 3.10 (20). Duncan's Multiple Range Test was accomplished for means comparison at $\mathrm{P}<0.05$ (21).

\section{Results}

Results related to occurrence of studied metals in local and imported cattle meat samples showed range and mean concentrations of $\mathrm{Pb}, \mathrm{Cr}$ and $\mathrm{Co}$ in local cattle meat 0.0162.11 (0.136), 0.013-0.92 (0.0651) and 0.002-0.089 (0.008) $\mathrm{mg} / \mathrm{kg}$, respectively, whereas $\mathrm{Pb}$ and $\mathrm{Cr}$ presented the higher significant levels. In imported cattle meat, results reported range and mean concentrations of the aforementioned metals $0.012-2.34$ (0.182), 0.004-1.65 (0.0486) and 0.004-0.21 (0.00971 $\mathrm{mg} / \mathrm{kg})$, respectively, where $\mathrm{Pb}$ showed the higher significant level. No significant differences between local and imported cattle meat in their metals content were reported (Table 1).

Results concerning $\mathrm{Pb}, \mathrm{Cr}$ and $\mathrm{Co}$ levels in local and imported buffalo meat were illustrated in table 2. In local buffalo meat, results showed range and mean concentrations of $\mathrm{Pb}, \mathrm{Cr}$ and $\mathrm{Co}$ 0.01-3.03 (0.119), 0.009$2.03(0.0896)$ and $0.002-0.15(0.017) \mathrm{mg} / \mathrm{kg}$, respectively. 
Samples obtained from imported buffalo meat presented $\mathrm{Pb}, \mathrm{Cr}$ and $\mathrm{Co}$ range and mean concentrations of 0.014-2.66 (0.106), 0.016-1.74 (0.102) and 0.003-0.1 (0.041) mg/kg, respectively. Results of statistical analysis showed no significant differences in the mean concentrations of $\mathrm{Pb}, \mathrm{Cr}$ and Co within the same meat type local or imported, and between local and imported buffalo meat in their metals content (Table 2). Also, no significant differences between cattle and buffalo meat (local and imported) in their content of studied metals were reported (Table 3 and 4).

Table 1: Range and mean concentrations $(\mathrm{mg} / \mathrm{kg})$ of lead, chromium and cobalt in local and imported cattle meat

\begin{tabular}{lccccccc}
\hline \multirow{2}{*}{ Meat type } & Samples & \multicolumn{2}{c}{$\mathrm{Pb}$} & \multicolumn{2}{c}{$\mathrm{Cr}$} & \multicolumn{2}{c}{ Co } \\
\cline { 3 - 8 } & No. & Range & Mean \pm SE & Range & Mean \pm SE & Range & Mean \pm SE \\
\hline Local & 40 & $0.016-2.11$ & $0.136 \pm 0.0552 \mathrm{a}$ & $0.013-0.92$ & $0.0651 \pm 0.0244 \mathrm{ab}$ & $0.002-0.089$ & $0.008 \pm 0.0021 \mathrm{~b}$ \\
Imported & 40 & $0.012-2.34$ & $0.182 \pm 0.0711 \mathrm{a}$ & $0.004-1.65$ & $0.0486 \pm 0.0411 \mathrm{~b}$ & $0.004-0.21$ & $0.00971 \pm 0.0051 \mathrm{~b}$ \\
\hline
\end{tabular}

Vertically and horizontally different letters are significantly different at $\mathrm{P}<0.05$.

Table 2: Range and mean concentrations ( $\mathrm{mg} / \mathrm{kg}$ ) of lead, chromium and cobalt in local and imported buffalo meat

\begin{tabular}{lccccccc}
\hline \multirow{2}{*}{ Meat type } & Samples & \multicolumn{2}{c}{$\mathrm{Pb}$} & \multicolumn{2}{c}{$\mathrm{Cr}$} & \multicolumn{2}{c}{ Co } \\
\cline { 3 - 8 } & No. & Range & Mean \pm SE & Range & Mean \pm SE & Range & Mean \pm SE \\
\hline Local & 40 & $0.01-3.03$ & $0.119 \pm 0.0752 \mathrm{a}$ & $0.009-2.03$ & $0.0896 \pm 0.0567 \mathrm{a}$ & $0.002-0.15$ & $0.017 \pm 0.0040 \mathrm{a}$ \\
Imported & 40 & $0.014-2.66$ & $0.106 \pm 0.0659 \mathrm{a}$ & $0.016-1.74$ & $0.102 \pm 0.0515 \mathrm{a}$ & $0.003-0.1$ & $0.041 \pm 0.0043 \mathrm{a}$ \\
\hline
\end{tabular}

Vertically and horizontally different letters are significantly different at $\mathrm{P}<0.05$.

Table 3: Comparison between local cattle and buffalo meat in their contents of lead, chromium and cobalt

\begin{tabular}{lccc}
\hline Animal & \multicolumn{3}{c}{ Mean $\pm \mathrm{SE}(\mathrm{mg} / \mathrm{kg})$} \\
\cline { 2 - 4 } species & $\mathrm{Pb}$ & $\mathrm{Cr}$ & $\mathrm{Co}$ \\
\hline \multirow{2}{*}{ Cattle } & 0.136 & 0.0651 & 0.008 \\
& $\pm 0.0552 \mathrm{a}$ & $\pm 0.0244 \mathrm{a}$ & $\pm 0.00212 \mathrm{a}$ \\
Buffalo & 0.119 & 0.0896 & 0.017 \\
& $\pm 0.0752 \mathrm{a}$ & $\pm 0.0567 \mathrm{a}$ & $\pm 0.00404 \mathrm{a}$ \\
\hline
\end{tabular}

Vertically similar letters are not significantly different at $\mathrm{P}<0.05$.

Distribution of $\mathrm{Pb}$ in 160 samples of local and imported cattle and buffalo meat (40 samples for each) (Figure 1). Eight samples from each local cattle and buffalo meat 20\% were exceeded the maximum acceptable limit proposed by European Union (EU) for lead in meat $0.1 \mathrm{mg} / \mathrm{kg}$. Also, five samples of imported cattle meat $12.5 \%$ and nine samples of imported buffalo meat $22.5 \%$ were higher than the permissible limit.

Concerning $\mathrm{Cr}$, samples exceeded the maximum allowable limit for $\mathrm{Cr}$ (Figure 2), which reported that from 40 samples of each meat type, only one sample of imported cattle meat $2.5 \%$ and 2 samples from each of local and imported buffalo meat 5\% were exceeded the maximum permissible limit for $\mathrm{Cr}$ in meat as proposed by the United States Department of Agriculture (USDA) $1 \mathrm{mg} / \mathrm{kg}$.

Finally, results recorded that all samples of cattle and buffalo meat (local and imported) were within the maximum acceptable limits for Co according to Food and
Agriculture Organization/ World Health Organization (FAO/WHO) $1 \mathrm{mg} / \mathrm{kg}$. (Figure 3).

Table 4: Comparison between imported cattle and buffalo meat in their contents of lead, chromium and cobalt

\begin{tabular}{lccc}
\hline Animal & \multicolumn{3}{c}{ Mean $\pm \mathrm{SE}(\mathrm{mg} / \mathrm{kg})$} \\
\cline { 2 - 4 } species & $\mathrm{Pb}$ & $\mathrm{Cr}$ & $\mathrm{Co}$ \\
\hline \multirow{2}{*}{ Cattle } & 0.182 & 0.0486 & 0.00971 \\
& $\pm 0.0711 \mathrm{a}$ & $\pm 0.0411 \mathrm{a}$ & $\pm 0.00514 \mathrm{a}$ \\
Buffalo & 0.106 & 0.102 & 0.041 \\
& $\pm 0.0659 \mathrm{a}$ & $\pm 0.0515 \mathrm{a}$ & $\pm 0.00431 \mathrm{a}$ \\
\hline
\end{tabular}

Vertically similar letters are not significantly different at $\mathrm{P}<0.05$.

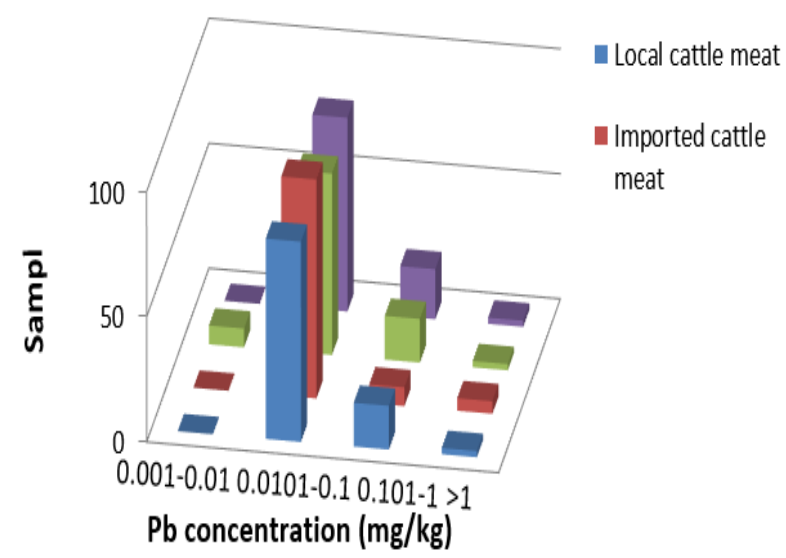

Figure 1: Occurrence of $\mathrm{Pb}(\mathrm{mg} / \mathrm{kg})$ in cattle and buffalo meat 


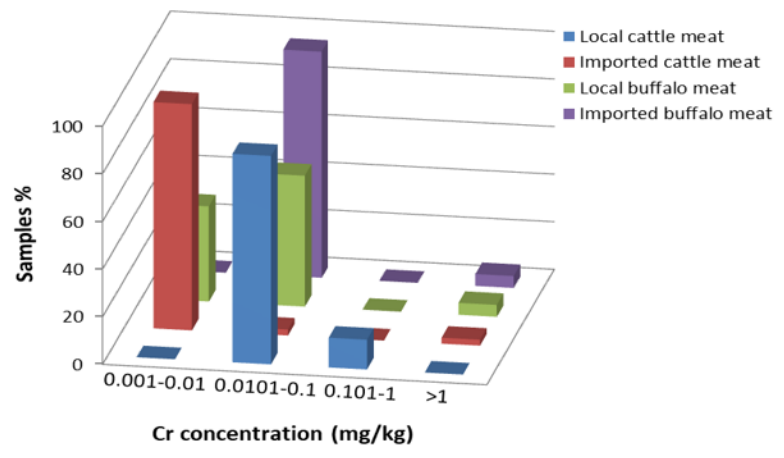

Figure 2: Occurrence of $\mathrm{Cr}(\mathrm{mg} / \mathrm{kg})$ in in cattle and buffalo meat

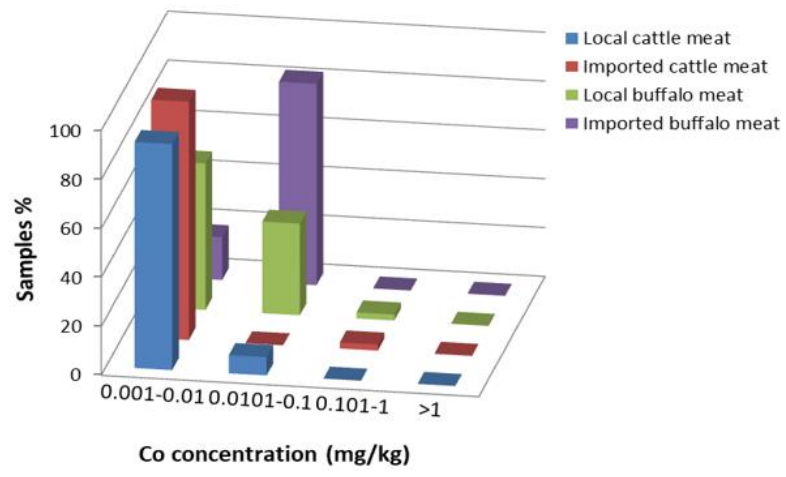

Figure 3: Occurrence of $\mathrm{Co}(\mathrm{mg} / \mathrm{kg})$ in in cattle and buffalo meat

\section{Discussion}

Heavy metals residues have acquired particular concern due to these metals cannot be disintegrated and exist permanently in the environment (22). For this reason, contamination of human food with these metals at toxic levels is certainly constitutes a serious problem for human health.

Results reported that $\mathrm{Pb}$ presented the higher levels, then $\mathrm{Cr}$ whereas Co showed the lowest levels in both local and imported meat of cattle and buffalo. These results were in agreement with the results of the study reported by Abd EI-Salam and coworkers (23), which revealed that $\mathrm{Pb}, \mathrm{Cr}$ and Co levels in cattle and buffalo meat were 2.7, 0.3 and 0.138 and $3.25,0.488$ and $0.05 \mathrm{mg} / \mathrm{kg}$, respectively. Also, results were accommodating with the results recorded by Nkansah and Ansah (14) which stated that $\mathrm{Pb}$ was presented in meat at levels $0.237-1.154 \mathrm{mg} / \mathrm{kg}$ higher than that for $\mathrm{Cr} 0.0472-0.957 \mathrm{mg} / \mathrm{kg}$. On the other hand, results were in contrast with the results offered by Yakup and colleagues (12) who showed that $\mathrm{Pb}$ was detected in cattle and buffalo meat at concentrations 0.702 and $0 \mathrm{mg} / \mathrm{kg}$, respectively lower than those found for Co 1.042 and 0.497 $\mathrm{mg} / \mathrm{kg}$, respectively.

These variations in $\mathrm{Pb}, \mathrm{Cr}$ and Co levels in meat were attributed to several factors including dietary habits, water and feed sources, place and age of animals, butcher shop place, meat origin, conditions of meat transportation and offering, in addition to other environmental conditions (13). No significant differences between meat of cattle and buffalo (local and imported) in their content of $\mathrm{Pb}, \mathrm{Cr}$ and Co were recorded. Our study was in coincide with the studies mentioned by $(24,25)$ which revealed that $\mathrm{Pb}$ concentrations in cow's and buffalo's meat was not significantly different. Results were incompatible with (23) who showed significant differences between cattle and buffalo meat in their metals content of $\mathrm{Pb}, \mathrm{Cr}$ and $\mathrm{Co}$.

\section{Conclusion}

Our study exposed substantial information about $\mathrm{Pb}, \mathrm{Cr}$ and Co levels in local and imported cattle and buffalo meat. Although all meat samples were within the maximum permissible limits for $\mathrm{Co}$, but special attention should be focused about $\mathrm{Pb}$ and $\mathrm{Cr}$ levels in meat as they present at levels higher than the tolerable limits in some meat samples. Strict legislations should be adopted concerning heavy metals levels in meat and other foodstuffs in order to provide safe products to the consumers.

\section{Acknowledgments}

Authors wish to thank the College of Veterinary Medicine, University of Mosul for support and providing facilities. Appreciation is also extended to the Department of General Science, College of Basic Education, University of Mosul for samples analysis with atomic absorption spectrophotometer.

\section{Conflict of interest}

The authors certify that they have no conflict of interest.

\section{References}

1. Williams P. Nutritional composition of red meat. Nutrition \& Dietetics. Wiley. 2007; 64(4): 113-119. $\quad \underline{10.1111 / j .1747-}$ $\underline{0080.2007 .00197 . \mathrm{x}}$

2. Ahmad RS, Imran A, Hussain MB. Nutritional Composition of Meat. Meat Science and Nutrition. In Tech. 2018. 10.5772/intechopen.77045

3. Demirezen D, Uruç K. Comparative study of trace elements in certain fish, meat and meat products. Meat Science. Elsevier BV. 2006; 74(2): 255-60. 10.1016/j.meatsci.2006.03.012

4. Montoro R, Vélez D. Detecting metal contamination. In: Watson DH. ed. Pesticide, Veterinary and Other Residues in Food. Elsevier. 2004; 610-40. 10.1533/9781855739109.4.610 
5. Goyer RA, Clarkson TW. Toxic effects of metals. In: Klaassen CD. ed. Casarett and Doull's Toxicology: The basic science of poisons. 6th ed., McGraw-Hill companies, Inc., USA. 2001: 861-867. https://www.scirp.org/(S(vtj3fa45qm1ean45vvffcz55))/reference/Refe rencesPapers.aspx?ReferenceID $=1883135$

6. Hajeb P, Sloth JJ, Shakibazadeh S, Mahyudin NA, Afsah-Hejri L. Toxic Elements in Food: Occurrence, Binding, and Reduction Approaches. Comprehensive Reviews in Food Science and Food Safety. Wiley. 2014; 13(4):457-72. 10.1111/1541-4337.12068

7. Flora G, Gupta D, Tiwari A. Toxicity of lead: a review with recent updates. Interdisciplinary Toxicology. Walter de Gruyter GmbH. 2012; 5(2):47-58. 10.2478/v10102-012-0009-2

8. Zahran AD, Hendy BA. Heavy metals and trace elements composition in certain meat and meat products sold in Egyptian markets. Internat J Sci: Basic Appl Res. IJSBAR. 2015; 20(1): 282-293. http://citeseerx.ist.psu.edu/viewdoc/download?doi=10.1.1.676.4699\&r ep=rep1\&type=pdf

9. Santhi D, Balakrishnan V, Kalaikannan A, Radhakrishnan KT. Presence of heavy metals in pork products in Chennai (India). Am J Food Technol. 2008; 3(3): 192-199. 10.ajft.2008.192.199

10. Al-Naemi HS. Estimation of lead and cadmium levels in muscles, livers and kidneys of slaughtered cattle in Mosul city. Mesopotamia J Agric. 2011; 39(3):8-16. 10.33899/magrj.2011.31125

11. Al-Zuhairi WS, Farhan MA, Ahmed MA. Determine of heavy metals in the heart, kidney and meat of beef, mutton and chicken from Baquba and Howaydir market in Baquba, Diyala Province, Iraq. Internat J Recent Sci Res. 2015; 6 (8): 5965-5967. http://www.recentscientific.com

12. Yakup NY, Sabow AB, Saleha SJ, Mohammed GR. Assessment of heavy metal in imported red meat available in the markets of Erbil City. J University Babylon, Pure and Applied Sci. 2018; 26 (6): 177-183.

ttps://www.journalofbabylon.com/index.php/JUBPAS/article/view/14 69

13. Chowdhury MZA, Siddique ZA, Hossain SA, Kazi AI, Ahsan AA, Ahmed S, Zaman MM. Determination of essential and toxic metals in meats, meat products and eggs by spectrophotometric method. J Bangladesh Chem Society. 1970; 24(2):165-172. 10.3329/jbcs.v24i2.9705

14. Nkansah MA, Ansah JK. Determination of $\mathrm{Cd}, \mathrm{Hg}, \mathrm{As}, \mathrm{Cr}$ and $\mathrm{Pb}$ level in meat from the Kumasi central abattoir. Internat J Sci Res Publications. 2014; 4 (8): 1-4. http://ijsrp.org/

15. Nawaz R, Ur Rehman S, Nawaz S, Iftikhar B. Analysis of heavy metals in red meat in District Peshawar Khyber Pakhunkhwa. J Med
Sci. 2015; 23(3): $\quad$ 166-171. https://pdfs.semanticscholar.org/f9e4/cdeb29404c5318d35f453f5b243 553980f46.pdf

16. Brito G, Díaz C, Galindo L, Hardisson A, Santiago D, García Montelongo F. Levels of metals in canned meat products: Intermetallic correlations. Bulletin of Environmental Contamination and Toxicology. Springer Science and Business Media LLC. 1990; 44(2):309-16. 10.1007/bf01700152

17. 1. Lopez Alonso M, Benedito JL, Miranda M, Castillo C, Hernandez J, Shore RF. Toxic and trace elements in liver, kidney and meat from cattle slaughtered in Galicia (NW Spain). Food Addit Contam. Informa UK Limited. 2000; 17(6):447-57. $10.1080 / 02652030050034028$

18. Al-Baggou' BK. Neurobehavioral and biochemical changes induced by interaction between cadmium and some insecticides in mice. $[\mathrm{PhD}$ Dissertation]. Mosul: Mosul University, 2002. 35 p.

19. Iwegbue CM. Heavy metal composition of livers and kidneys of cattle from southern Nigeria. Vet Arhiv. 2008; 78 (5): 401-410. https://hrcak.srce.hr/28916

20. Steel RG, Torrie JH. Principles and procedures of statistics. (with special reference to the biological sciences). McGraw- Hill Book Company, New York, Toronto, London. 1960. 10.1002/bimj.19620040313

21. Duncan DB. Multiple Range and Multiple F Tests. Biometrics. JSTOR. 1955;11(1):1. 10.2307/3001478

22. Baykov BD, Stoyanov MP, Gugova ML. Cadmium and lead bioaccumulation in male chickens for high food concentrations. Toxicol Environ Chem. Informa UK Limited. 1996; 54(1-4): 155-9. $10.1080 / 02772249609358308$

23. Abd EI-Salam NM, Ahmad S, Basir A, Rais AK, Bibi A, Ullah R, Shad AA, Muhammad Z, Hussain I. Distribution of heavy metals in the liver, kidney, heart, pancreas and meat of cow, buffalo, goat, sheep and chicken from Kohat market Pakistan. Life Sci J. 2013; 10(7s): 937-940. http://www.lifesciencesite.com/

24. Khalafalla FA, Abdel-Atty NS, Abd-El-Wahab MA, Ali OI, AboElsoud RB. Assessment of heavy metal residues in retail meat and $\begin{array}{lllll}\text { offals. J Am } & \text { Sci. 2015; 11(5): 50-54. }\end{array}$ http://www.jofamericanscience.org/

25. Gulsanga G, Anjum Z, Alam S, Shehzad F. Heavy Metals and Mineral Contents of Beef Sold at University Campus, Peshawar, Khyber Pakhtunkhwa, Pakistan. Sarhad J Agric. Researchers Links Ltd. 2018; 34(2):471-477. 10.17582/journal.sja/2018/34.2.471.477 